\title{
How animals negotiate odor space in evolutionary- and real-time
}

\author{
Tristram D Wyatt \\ From 1st International Workshop on Odor Spaces \\ Hannover, Germany. 4-7 September 2013
}

The sensory odor space perceived by animals depends on their chemosensory repertoire - this information is used for the essential decisions in life [1,2]. This information is also used to negotiate the real-world 3-dimensional odor landscape to find food or a mate.

The sensory odor space evolves as receptor families are co-opted and then undergo birth-and-death duplications, deletions and changes in response to natural selection. Insect and vertebrate olfactory receptors evolved independently. So, when male elephants and moths share the same odor space, with a shared molecule used as a female sex pheromone, we know that the receptors activated by the molecule are completely different and that they have evolved this sensitivity convergently.

Finding most odor sources relies on the second key concept underlying olfaction, combinatorial processing leading to synergy: a behavioral response to the combination greater than the response to individual components of the blend. The co-occurrence of odorant molecules in the same parcel of air or water is what gives meaning to the odorscape. A moth pheromone may consist of molecules which are not rare in themselves. However, when they co-occur in a unique combination, they become the guiding signal for a male to orient upwind. The excitement of particular multiple glomeruli gives the meaning to the signal. Orientation behavior to find the source relies on this real-time combinatorial processing of sensory inputs, responding millisecond by millisecond to the filamentous plumes of odorants carried by wind or air.

Anthropogenic $\mathrm{CO} 2$ and the acidification of the oceans are a threat to the odor space relied on by ocean life. As $\mathrm{pH}$ drops, the interactions between odorants and receptors change because the physicochemical properties of odor molecules are affected as are the binding sites of the receptors themselves.

Correspondence: tristram.wyatt@zoo.ox.ac.uk

Department of Zoology, University of Oxford, UK
Will this lead to chemosensory "blindness", with animals unable to find food or mates by the usual chemosensory stimuli? In the worst scenario, finding Nemo will become an impossible task.

Published: 16 April 2014

\section{References}

1. Wyatt TD: Pheromones and signature mixtures: defining species-wide signals and variable cues for identity in both invertebrates and vertebrates. J Comp Physiol A Neuroethol Sens Neural Behav Physiol 2010, 196:685-700.

2. Wyatt TD: Pheromones and animal behavior: chemical signals and signature mixtures. Cambridge: Cambridge University Press; 22014.

doi:10.1186/2044-7248-3-S1-P22

Cite this article as: Wyatt: How animals negotiate odor space in evolutionary- and real-time. Flavour 2014 3(Suppl 1):P22.
Submit your next manuscript to BioMed Central and take full advantage of:

- Convenient online submission

- Thorough peer review

- No space constraints or color figure charges

- Immediate publication on acceptance

- Inclusion in PubMed, CAS, Scopus and Google Scholar

- Research which is freely available for redistribution
() Biomed Central 